DOI: 10.15503/onis2014-212-221

\title{
NiE-LUdZKIE ARCYLUdZKIE - TADEUSZA KANTORA GRY Z MATERIĄ
}

\author{
Magdalena Skrzypczak, magdalenaskrzypczak@op.pl \\ Uniwersytet Łódzki \\ Ul. Narutowicza 65, Łódź
}

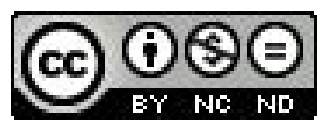

\section{STRESZCZenie}

Autorkę artykułu interesuje status wybranych aspektów materii, tandeta i atrapa w twórczości Tadeusza Kantora. W szkicu podejmuje ona próbę odpowiedzi na pytanie, czym jest materia, przedmiot, jego resztka, strzęp, skrawek, które uwodzą nie tylko wyobraźnię twórczą artystów, ale niemalże zmuszają szerokie grono odbiorców sztuki i potencjalnych interpretatorów do wnikliwej analizy residuum, z którym przyszło im obcować. Autorka szkicu nawiązuje również do humanistyki nieantropocentrycznej i do koncepcii materii Brunona Schulza.

Słowa kluczowe: Tadeusz Kantor, materia, tandeta, atrapa, bio-obiekt, ambalaż, przedmiot biedny

Non-human (all too human). Tadeusz Kantor's games with matter

\section{Abstract}

The paper focuses on the chosen aspects of matter, the shoddy and the dummy in Tadeusz Kantor's oeuvre. It is also an attempt to answer the question of the artistic genealogy of matter, an object, its remnant, shred, or scrap, which seduce artists' imagination, and how it is possible that shoddy objects inspire potential researchers and interpreters to analyze this peculiar residuum. The author of the article recalls Kantor's strange figures, bio-objects, in the context of the concept of matter by Bruno Schulz and the contemporary idea of non-anthropocentrism.

Keywords: Tadeusz Kantor, matter, shoddy, dummy, bio-object, emballage, poor object

Na wstępie chciałabym zadać pytanie, które nie domaga się odpowiedzi, ale niejako patronuje niniejszemu szkicowi czy tandeta wodzi na pokuszenie? Czym jest materia, przedmiot, jego resztka, strzęp, skrawek, które nieustannie uwodzą nie tylko wyobraźnię twórczą artystów, ale niemalże zmuszają szerokie grono odbiorców sztuki vel potencjalnych komentatorów/interpretatorów do wnikliwej analizy residuum, z którym przyszło im obcować?

Przedmiotem artykułu jest status wybranych aspektów materii, tandeta i atrapa w twórczości Tadeusza Kantora oraz ich - by tak rzec - geneaologia materialna i metamorfoza. Odwołując się miedzy innymi do definicji bio-obiektu T. Kantora, spróbuję ustalić pochodzenie tego amalgamatycznego organizmu, przyjrzę się wybranym przykładom autonomicznego (,,osobnego") tworu nie tylko w kontekście estetyki groteski czy makabreski, ale filozofii egzystencjalnej. We wszystkich realizacjach T. Kantora pojawiają się niepokojące sobowtórowe kreacje (le double), hybrydyczne postaci, kuriozalne figury, które domagają się dookreśleń, dopowiedzeń, komentarzy. Dodam, że interesuje mnie również forma zapisu/opisu tych figur w partyturach (językowych auto-replikach spektaklu) T. Kantora. W swojej wypowiedzi nawiążę również do twórczości artystów o wyobraźni pokrewnej T. Kantorowi, którzy w swoich utworach przywoływali podobne figury, kurioza i podejrzane indywidua, niepokojące typy przywodzące na myśl istotę ludzka, będące - jedynie pozornie - w opozycji względem niej.

Obok Jerzego Grotowskiego, T. Kantor był jednym z największych reformatorów teatru XX w. Sztuka tego „,wiecznego awangardzisty"1, jego malarstwo, rysunki, ale także pisarstwo, które charakteryzowało się szczególną troską o słowo i dbałością o strukturę wiersza (wersowe rozczłonkowanie tekstu) stanowiły ważne dopełnienie jego eksploracji teatralnych. Zgodnie z terminologią Edwarda Gordona Craiga, T. Kantor był nie tylko reżyserem, ale „artystą teatru”2.

Niniejszy tekst stanowi również próbę odpowiedzi na pytanie, czy bio-obiekt można rozumieć jako kreację wyrosłą z doświadczenia "afazji pamięci” artysty - wobec tego - czy ciało hybrydyczne może stać się również sygnałem niemożności scalenia „resztek” przeszłości? Czym/kim wówczas byłby dla T. Kantora ten „potworny okaz antropologiczny”

1 K. Pleśniarowicz, Teatr Śmierci Tadeusza Kantora, Chotomów 1990, s. 9

2 Zob. E. G. Craig, O sztuce teatru, Warszawa 1985. 
$(\text {,zoologiczny" })^{3}$ i w jaki sposób ów pozornie nie-ludzki twór uruchamia tak wiele dyskursów, ogarniając zagadnienia z zakresu eschatologii, antropologii, metafizyki czy ontologii?

T. Kantor zwrócił uwagę na przedmiot w ogóle. Nie ograniczył się do konwencjonalnego w teatrze oglądu rzeczy jako rekwizytu. Wyposażył przedmiot „Zwykły” w dodatkową wartość - niemal perwersyjna, demoniczną siłę. Co ważne, śladem Brunona Schulza, swojego estetycznego antenata, uniezwyklił materię. T. Kantor wydobywając „,czystą" przedmiotowość rzeczy i uwalniającją od funkcji służebnej, od jej użyteczności, upodmiotowił przedmiot. W eseju pt. Przedmiot biedny zapisał:

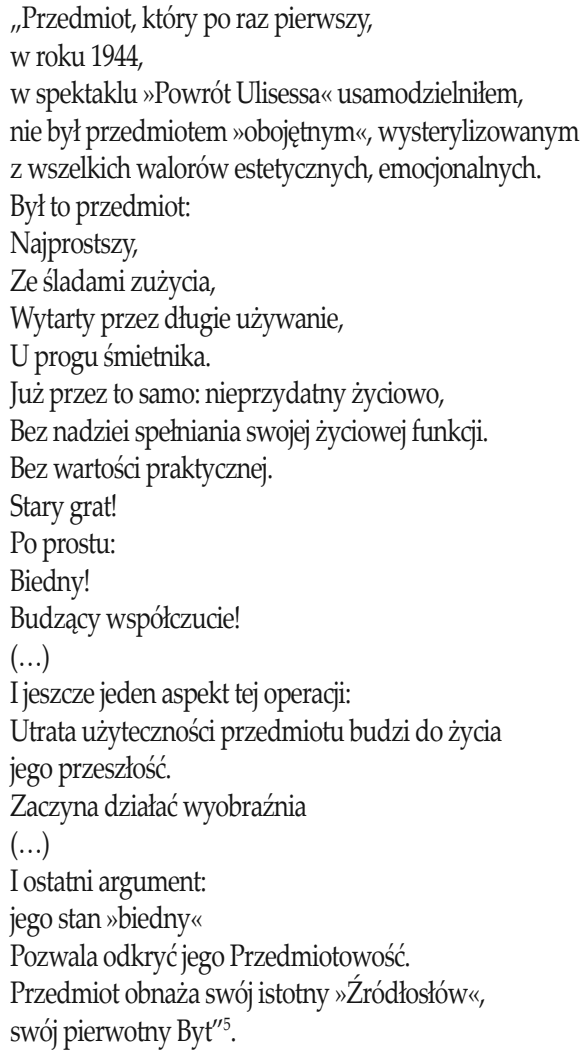

Z kolei w rozmowie z Wiesławem Borowskim T. Kantor przyznał, że choć operowanie realnością w sztuce ma swoje źródło w intelektualnym geście Marcela Duchampa, to jego pomysł odbiega już od kazusu readymade i Duchampowskiej Fontanny, Suszarki do butelek bądź Szufli do śniegu' . Wówczas, w właściwym sobie tonie, potępił rzesze biernych naśladowców francuskiego awangardzisty: „Dopiero kontynuatorzy i plagiatorzy, działający aż do dzisiaj, zrobili z tego potworną łatwiznę. Ja nie operuję przedmiotem »jakimkolwiek«, ani tak zwanym przedmiotem »zwyczajnym«, "prostym«, »surowym«. (...) Ani unikalnym, ani seryjnym. Nie chodzi mi także o przedmiot znaleziony. Kieruję swoją uwagę w stronę rzeczywistości, która ma najniższą rangę w powszechnej opinii, $\mathrm{w}$ sferę przedmiotów, które są lekceważone, zapomniane, banalne, nieważne. (...) Przez powszechne użycie przedmiot taki staje się kompletnie niewidzialny. Gdy jest utylitarny,

3 T. Kantor, Pisma. Teatr Śmierci. Teksty z lat 1975-1984, T. II, Wrocław-Kraków 2004, s. 52-53.

4 W kontekście wspomnianej wartości residuum, strzępów, resztek (materii/materiału), literackiego krawiectwa (do-krajania) można w tym miejscu wspomnieć, że Bruno Schulz był twórcą literatury haute couture - skrojonych z największą precyzją słów, jednych z najdoskonalszych i najlepiej skonstruowanych opowiadań literatury polskiej XX w.

5 T. Kantor, Pisma, T. II, dz. cyt., s. 415-416.

6 W. Borowski, Tadeusz Kantor, Warszawa 1982, s. 18 
familiaryzujemy się z nim; uniezależniamy się dopiero, gdy straci swą utylitarność, ale wtedy go porzucamy bądź wyrzucamy na śmietnik"7.

Zatem rzeczy/obiekty/przedmioty skrzętnie wyłuskane z codzienności, obmyte z jej kurzu, odrodzone w swej niezależności, stały się przedmiotem refleksji artystycznej T. Kantora. Po raz wtóry w historii sztuki artysta tchnął ducha w materię. Niektóre spośród jego artystycznych kreacji nawiązują do popularnej na gruncie współczesnej humanistyki nieantropocentrycznej wizji świata. Należy w tym miejscu nawiązać do refleksji Brunona Latour'a, autora projektu socjologii krytycznej, który postuluje zastąpienie terminu „społeczność" pojęciem „kolektywu”, odzwierciedlającego nieustanne współdziałanie, oddziaływanie bytów ludzkich i nie-ludzkich ${ }^{8}$. Wystarczy wspomnieć, że B. Latour skrytykował socjologię jako naukę wyłącznie o tym, co społeczne na rzecz nauki o związkach poszczególnych elementów rzeczywistości (teoria ANT, aktora-sieci). W swoich rozważaniach dotyka również tkanki teatralnej, stwierdzając, że posługuje się terminem „aktora” dla określenia bytów nie-ludzkich jako aktywnych podmiotów sprawczych' ${ }^{9}$ Otóż aktor na scenie jest jedną z takich części spektaklu, bytem igrającym w złożonej sieci działających podmiotów sprawczych. Twórczość T. Kantora włącza materię nieożywioną w teatralny krwiobieg. Dzięki temu w jego artystycznym projekcie wszystko się z sobą płynnie splata, element pozornie martwy przekazuje swoją energię innym podmiotom sprawczym.

Jak zauważyła Ewa Domańska ${ }^{10}$, kiedy w kontekście „zwrotu performatywnego"111 badacze wspominają o problemie sprawczości, ich rozważania zaczynają oscylować wokół bytów nie-ludzkich ${ }^{12}$. W krytyce antropocentryzmu zwraca się bowiem uwagę na sprawczość artefaktów. Człowiek nie jest wyabstrahowanym, samotnym elementem rzeczywistości i świata. Współtworzy sieć precyzyjnie „(współ)utkaną” przez materię nieożywioną. Wszelka zmiana w świecie jest uwarunkowana aktywną współpraca, kooperacją podmiotów sprawczych. E. Domańska w ramach egzemplifikacji przywołuje w swoim szkicu m. in. eksperymenty T. Kantora z „przedmiotem biednym”. Zdaniem badaczki twórca teatru Cricot 2, gdy już obrał przedmiot za wyznacznik granic sztuki, uwolnił (alienował) rzeczy od człowieka, podczas gdy badacze zajmujący się transhumanizmem neutralizują bądź znoszą ten podział. Jest to teza, z którą można by polemizować. Skoro "przedmiot biedny" w twórczości artysty stał się częścią sprawnie funkcjonującej kreatury lub mechanizmu i wniósł w ten twór całą swoją „,przeszłość”, , „swój pierwotny byt", nie można redukować jego znaczenia. Rzecz z całą swoją „,przedmiotową pamięcią" nie jest izolowana, wręcz przeciwnie - stanowi wraz z „żywym ciałem” osobliwy amalgamat - kompozycję strumienia życia i pozornej śmierci.

W tym miejscu sygnalizuję jedynie sporych rozmiarów temat humanistyki nieantropocentrycznej i aktualny problem podmiotu posthumanistycznego we współczesnej kulturze i sztuce.

W kontekście refleksji nad naturą konglomeratu: ludzkie i nie-ludzkie, materia ożywiona i nieożywiona (bios vs zoe), warto dodać, że nie tylko teatr T. Kantora, ale całą jego twórczość można by opisać jako gigantyczny, pulsujący, autonomiczny „organizm”. Sercem tej „Żywej” machiny artystycznej byłby on sam. Zawsze obecny na scenie, pospieszający swoich aktorów charakterystycznym gestem - strzepnięciem palców. Nie sposób nie dostrzec, że było coś mistycznego w jego byciu na scenie-postać i nie-postać, „rola" i „nie-rola”. Natomiast z pewnością przywodził on na myśl dyrygenta, partycypującego w spektaklu, a zarazem we fluktuacji życia i śmierci ${ }^{13}$. T. Kantor pytany o swoją obecność na scenie i o to, co zyskuje niszcząc iluzję, odpowiadał, że spektakl jest dla niego „ostatnią potrzebą" , „chwilą przed zgaśnięciem”. Twierdzit, że musi być ze swoimi aktorami w ich "ostatniej potrzebie". Musi być obecny - ,jak przy rozstrzelaniu"14.

7 Tamże.

8 B. Latour, Splatając na nowo to, co spoleczne. Wprowadzenie do teorii aktora-sieci, Kraków 2010.

9 Tamże, s. 65-66.

10 E. Domańska, „Zwrot performatywny” we wspótczesnej humanistyce, http://www.staff.amu.edu.pl/ ewa/Domanska,\%20Zwrot\%20performatywny\%20we\%20wspolczesnej\%20humanistyce.pdf, 9.12.2013; Tejże, Humanistyka nie-antropocentryczna a studia nad rzeczami, http://www.staff.amu.edu. pl/ ewa/Domanska,\%20Humanistyka\%20nie-antropocentryczna\%200\%20studia\%20nad\%20rzeczami.pdf, 9.12.2013.

11 Termin ,Zwrot performatywny" bywa nazywany również paradygmatem performance'owym.

12 Polscy badacze, którzy nawiązywali do posthumanizmu oraz krytyki antropocentryzmu to m. in.: K. Krzysztofek, Czlowiek posthumanistyczny?, ,Kultura Wspótczesna" 1999, nr 1 (19); M. Bakke, Ciało otwarte. Filozoficzne reinterpretacje kulturowych wizji cielesności, Poznań 2000; M. Bakke, Nieantropocentryczna tożsamość, [w:]A. Gwóźdź, A. Ćwikiel(red.), Media/ciało/pamięć. O wspótczesnych tożsamościach kulturowych, Warszawa 2006; M. Bakke, Posthumanizm: czlowiek w świecie większym niż ludzki, [w:] J. Sokolski (red.), Czlowiek wobec natury - humanizm wobec nauk przyrodniczych, Warszawa 2010; M. Bakke, Bio-transfiguracje. Sztuka i estetyka posthumanizmu, Poznań 2010; E. Domańska, Ku historii nieantropocentrycznej, [w:] Tejże, Historie niekonwencjonalne. Refleksja o przeszlości w nowej humanistyce, Poznań 2006. Badania podmiotu posthumanistycznego podejmują również m. in. Elizabeth Grosz, Bruno Latour, Donna Haraway oraz Rosi Braidotti.

13 Wypowiedzi na temat wielowymiarowego/nieokreślonego statusu i niejednoznacznej funkcji T. Kantora - obecnego zawsze na scenie - pojawiają się niemal we wszystkich pracach kantorologów i komentatorów jego dzieła.

14 Rozmowa z Tadeuszem Kantorem (rozmawiał Krzysztof Miklaszewski); Zob. K. Miklaszewski (reż.), tadeuszkantor@europa.pl, 2010. 
Można pokusić się o stwierdzenie, że jego twórczość, pojęta holistycznie, jest czymś na kształt projektu metahumanistycznego. W kantorowskim świecie drzemał niepokój, dysonans nie tylko jednostkowego (autorskiego), ale przede wszystkim uniwersalnego doświadczenia. T. Kantor osiagnął efekt jakby „podskórnej”, metafizycznej komunikacji z odbiorcą (widzem, czytelnikiem), a dokładniej - z partycypującym, współuczestnikiem widowiska (tekstu kultury), domagającego się skrupulatnego od-czytywania. Artysta w wyrafinowany sposób cyzelował obrazy, zapisywał, szkicował je i zatrzymywał niczym w kadrze. Jego twórczość dotyka problemu ułomności oraz „niepełności” istnienia. Oscyluje wokół zagadnień wiążących się ze sposobem bycia człowieka w świecie. Chciałabym również zaznaczyć, że autor Umarłej klasy prowadził $\mathrm{w}$ ten sposób dialog z epoką romantyzmu, kiedy to indywiduum z jednostkowymi motywacjami (potrzebą znaczenia/sygnowania siebie w świecie) stało się przedmiotem zainteresowań artystów, filozofów i badaczy. Romantycznej proweniencji zdaje się także jego przekonanie o roli/powołaniu artysty. Poza tym tę linię - czasem trudnego, aporetycznego - pokrewieństwa może wyznaczać również fakt, że dzieła literackie romantyzmu charakteryzowały się fragmentarycznościa, achronologią i dygresyjnością. Romantyczne ułomki, ułamki, epizody, wyjątki i fragmenty były wyrazem ułomności funkcjonowania mechanizmu pamięci. Fragmentaryczność ekspresji koresponduje ze strukturą umysłu człowieka. W niniejszym szkicu nie ma miejsca na szczegółowe omówienie tej kwestii, ale chciałabym podkreślić fakt, że fragment - paradoksalnie - nie jest wyrazem ograniczonych kompetencji poznawczych człowieka, wręcz przeciwnie - najlepiej wyraża on ideę nieskończoności. Czegoś, co jest niewyrażalne i niepojęte w swej bezgraniczności nie da się wyeksplikować za pomocą tego, co jest skończone. Twórczość T. Kantora jest odpowiedzią na taki sposób oglądu świata. Może przywodzić na myśl artystyczne kolaże, mozaiki złożone ze wspomnieniowych klisz, strzępów i „,resztek” istnienia ekshumowanych z zakamarków pamięci. Skoro wspomnienie jest efektem żmudnej pracy pamięci i jako takie serwuje obrazy zdeformowane, niepełne, fragmentaryczne i „,kalekie", to może m.in. właśnie w tej aktywności należałoby doszukiwać się źródła kuriozalnych, zmultiplikowanych, hybrydycznych figur wyobraźni autora Umarłej klasy.

T. Kantor wprowadził na scenę cały szereg postaci groteskowych, będących raczej reinterpretacją ciała człowieka niż reminiscencją tegoż ${ }^{15}$. Wiąże się to z zapożyczoną przez T. Kantora od B. Schulza „ideą realności najniższej rangi”, którą zastosował po raz pierwszy przy okazji Powrotu Odysa, Balladyny, realizacji artystycznych, które powstały w ramach Teatru Niezależnego (zwanego również Teatrem Podziemnym, 1942-1944 r.) ${ }^{16}$ :

„....im przedmiot jest »niższej rangi«, tym większe ma szanse ujawnienia swej przedmiotowości - a podjęcie go z owych rejonów pogardy i śmieszności stanowi w sztuce akt czystej poezji...

....w teatrze:

treść sztuki, ową iluzję, którą przedstawia się zazwyczaj z użyciem wszelkich dostępnych środków - aranżować w warunkach śmiesznie szczupłych, jakoś biednie

(jak u dzieci)

jakieś patyczki, pudełka, wózki niefunkcjonujące, cichcem, chyłkiem, wstydliwie, lękliwie, ruchy enigmatyczne, wiadome tylko wykonawcom... robić wszystko, aby rezygnując z zewnętrznych usprawiedliwień i tzw. pełni wyrazu, dać wyczuć sferęi $\mathrm{m}$ a g i n a c y jn ą!

(...)

...W sferze imaginacyjnej mieszczą się te najwyższe sprawy...

byt, śmierć, miłość...

bez patosu i bez iluzij...

wystarczy do tego biedny kąt,

paka, kij, kółko od roweru...

...wynajdywać przedmioty, fakty, akcje, sytuacje życiowe tak niedostateczne, tak bezskutecznie praktyczne i tak bezcelowe, że tworzą »DZıURĘ« imaginacyjną...

żonglować

rzeczami śmiesznie błahymi,

15 Zob. m.in. K. Fazan, Gry z komizmem w Teatrze Śmierci, [w] Tejże, Projekty intymnego teatru śmierci. Wyspiański-Leśmian - Kantor, Kraków 2009; A. Królica, Groteskowe ciala. Kantor i wspótczesna choreografia, ,Performer” 2011, nr 2; M. Skrzypczak, Perwersia rekwizytu? Figura uczlowieczona i figura czlowieka w twórzzości Tadeusza Kantora, [w:] J. Niedbała, J. Podwysocka-Modrzejewska, B. Prokopczyk, J. Rozwandowicz (red.), Tekst-Tworzywo-Twórca, Łódź2011.

16 Natomiast dopiero w $1960 \mathrm{r}$., na etapie Teatru informel, idea przedmiotu ,biednego" i anektowania realności przyjęla pehną nazwę ,realność najniżzzej rangi".

OGRODY NAUK I SZTUK NR 2014 (4) 


$$
\begin{aligned}
& \text { wstydliwymi, } \\
& \text { poniżej godności, } \\
& \text { żenującymi, } \\
& \text { "śmieciem". } \\
& \text { byle czym, } \\
& \text { pu st ka!"17 }
\end{aligned}
$$

Do 1955 r. T. Kantor uprawiał malarstwo metaforyczne. Pobyt w Paryżu szybko mu uświadomił, że awangarda plastyczna zerwała z prawami konstrukcji w obrazie. Natomiast coraz większe znaczenie zaczęły odgrywać płynność, zmienna materia - oznaczające bios, przypadek i ruch. Z pozycii malarza T. Kantor dostrzegł, , jak skostniałym medium pozostał teatr"18. Teatr informel, który został powołany do życia w ramach Cricot $2 \mathrm{w} 1960 \mathrm{r}$. miał być integracją sztuki informel (amorficznej, abstrakcyjnej) z tkanką teatralną. W swoich notatkach T. Kantor szczegółowo opisał, jaka właściwość materii najbardziej go intrygowała: „materia nierządząca się prawami konstrukcji, ciągle zmienna i płynna, nieskończona, negująca pojęcie formy, która jest ograniczona i skończona, niepodlegająca żadnym zmianom, zakończona ${ }^{\prime 19}$. Materii zostały zatem przypisane takie „stany”, jak: nieforemność, spontaniczność działania, akcja, rozbicie, dekompozycja, rozkład, rozpad, destrukcja oraz przypadek. Wymienionym cechom i charakterowi materii T. Kantor nadał również dość enigmatycznie brzmiące „objawy różnych sfer życia ludzkiego" ${ }^{\prime 20}$. Informel stał się przyczynkiem do precyzyjnego skatalogowania różnych rodzajów materii, jak: ziemia, błoto, glina, gruz, próchno, popiół, gnój, ciasto, woda, dym czy ogieñ ${ }^{21}$. Okres informelu to czas coraz silniejszej fascynacji materiałami i przedmiotami „u progu przejścia w stan materii"22:

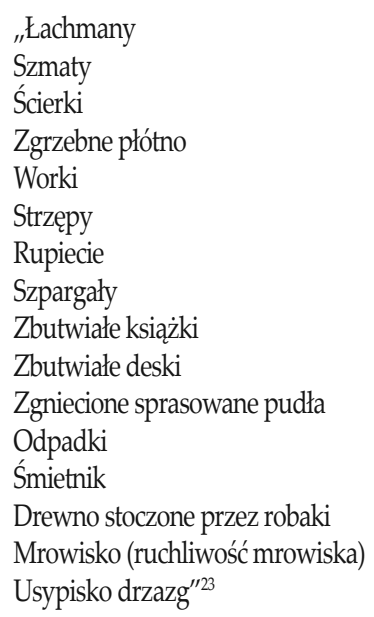

Z anektowaniem realności łączy się pojęcie „przedmiotu biednego" oraz „miejsca biednego". T. Kantor sięgał do najniższych rejestrów, wydobywając to, co zapomniane. Po raz wtóry w historii sztuki materia została ożywiona, a kukła i atrapa na powrót objawily się T. Kantorowi ze swoją „życiową" potencją. Dzięki takiemu podejściu do przedmiotu i materii, osobliwym inklinacjom do skądinąd znanej demiurgii, T. Kantor tworzył/kształtował swoją wrażliwość estetyczną. Artefakt („przedmiot artystyczny" - dzieło sztuki) zastąpił przedmiotem i usytuował go na równi z aktorem - przedmiot

17 T. Kantor, Pisma, T. II, dz. cyt., s. 417-418.

18 L. Stangret, Umarla klasa, [w:]A. Welmiński, Trumpf, trumpf...: lalki, manekiny i przedmioty ze spektaklu ,_Umarla klasa” Tadeusza Kantora, Warszawa 2005 , s. 6 .

19 T. Kantor, Pisma, T. I, Metamorfozy. Teksty o latach 1934-1974, Wrocław-Kraków 2005, s. 183.

20 Tamże, s. 184.

21 Tamże, s. 185.

22 Tamże.

23 Tamże. 
„po prostu: BYŁ, ISTNIAŁ, - na równi z aktorem./BYŁ AKTOREM! Przedmiot-Aktor!!"24. Takich antropomorfizacyjnych momentów jest $w$ notatniku ${ }^{25}$ artysty wiele:

„Materia posiada swojeuroki,fascynacje,niebezpieczeństwa,swoje kataklizmyi swoje ocalenia.Ulega nieustannemu procesowirozpadu,

zniszczeniai rozkładu.

(...)Akt malarstwa odbywa się ponad tym nieustannym procesemaneantyzacii.Jest $\mathrm{w}$ tym $\mathrm{i}$ zabawaniemal dziecinna,imaginacja badawcza,i humor,i to działanie czasu,które nas zawsze fascynuje..."26

Jak wspomniałam, spośród całego katalogu materiałów i przedmiotów „u progu przejścia w stan materii” można wymienić: łachmany, szmaty, ścierki, zgrzebne płótno, worki (szczególnie ważne ze względu na to, że „w hierarchii przedmiotów posiadają najniższą rangę i jako takie z łatwością stają się b e z p r z e d m i o to w ą materią..." ${ }^{\prime \prime 2}$ ) itd. T. Kantor, upodmiotawiając przedmiot, skatalogował nawet stany emocjonalne (patologiczne) odpowiadające temu, co może dziać się z materią: ekscytację, egzagerację, stany halucynacyjne, gorączkowe, konwulsyjne, agonalne. Dodatkowo postanowił przypisać przedmiotom cechy ludzkie - włączył w rozważania nad materią określenia charakterystyczne dla obyczajów i sposobu zachowywania się, czyli: rozwiązłość, rozwydrzenie, wyuzdanie, występne procedery, grzeszne praktyki, sadyzm, okrucieństwo, lęk i wstyd ${ }^{28}$. Powyższe katalogi zapewne ułatwiły T. Kantorowi późniejsze refleksje nad metodą pracy z aktorami Cricot 2. Efektem wykorzystania metody informelle była realizacja W małym dworku (według tekstu Stanisława Ignacego Witkiewicza) i Nosorożca (wg dramatu Eugène'a Ionesco) w $1961 \mathrm{r}$.

Zczasem -jako continuum przedmiotu „,biednego" - T. Kantor wprowadził pojęcie bio-obiektu ${ }^{29}$. Po latach, w pisanym z perspektywy czasu eseju z $1981 \mathrm{r}$. pt. Miejsce teatralne T. Kantor ukonstytuował to pojęcie w odniesieniu do konstruktu złożonego z pierwiastka żywego (aktora) i przedmiotu/obiektu. Osobliwy konglomerat animalno-przedmiotowy jako autonomiczne dzieło sztuki (l'objet d'art.) posiadał: ,jedną osobliwość: własne, żywe organa: AKTORÓW"30. Konstrukt ten tworzył z aktorem nierozerwalną całość:

„BIO-OBIEKTY nie były rekwizytami, którymi aktorzy się posługują.Nie były »dekoracjami«, w których się "gra«. Tworzyły z aktorami nierozdzielną całość.Wydzielały z siebie swoje własne »życie«, autonomiczne, nieodnoszące się do FIKCJI (treści) dramatu.To »życie« i jego objawy tworzyły i s t o $t$ n ą treść spektaklu. Nie była to f a b u ła, a raczej m a t e r i a spektaklu.

Demonstrowanie i manifestowanie »życia« tego вІо-овІектu nie było p r z e d s t a w i a n i e m jakiegoś układu istniejącego poza nim.

Było autonomiczne, a więc r e aln e!

BIo-oBIEkT - dzieło sztuki"31

Bio-obiekt nie odsyłał do żadnego układu poza samym soba, nie był przedstawieniem, sam był "treścią". Aktorzy stawali się żywymi częściami składowymi - organami przynależnymi obiektowi. T. Kantor podkreślał, że „bez aktorów był ten przedmiot zdezelowanym w r a ki e m, niezdolnym do działania" ${ }^{\prime \prime 2}$. To osoba była określana przez obiekt i w tym sensie pozostawała od niego zależna (role i czynności aktorów „,wywodziły się z niego" ${ }^{33}$. Przy okazji opisu relacii bio-obiektów i fikcji (treści dramatu) T. Kantor posłużył się również terminem „prześwitywania" ${ }^{\prime 34}$.Zupełnie tak, jakby jedną z funkcji tego artystycznego konglomeratu było „przechwytywanie” fikcji, nagłe jej gubienie i równie „niespodziewany”

24 Tamże, s. 127

25 Notatnik. 1955 ... 1958... 1962 jest zbiorem redagowanych przez T. Kantora w latach siedemdziesiatych i osiemdziesiątych tekstów, zapisków, refleksji artystycznych. Był publikowany w języku francuskim, japońskim i niemieckim.

26 T. Kantor, Pisma, T. I, dz. cyt., s. 171.

27 Tamże, s. 327.

28 Tamże, s. 182-186.

29 Można wysnuć tezę, że przedmiot „biedny” ewoluował do postaci bio-obiektu, który z kolei mógłby zostać opisany jako inkarnacja tegoż.

30 T. Kantor, Pisma, T. II, dz. cyt., s. 397.

31 Tamże.

32 Tamże

33 Tamże.

34 Tamże. 
powrót treści dramatu (swobodne, cyrkowe igranie). W takim rozumieniu bio-obiekt byłby czymś na kształt medium, które pośredniczy nie tylko między realnością (materialnością) a fikcją ale pod którego przymusem aktor podejmuje akcje fabuły i rolę. Spośród przedmiotów, które wchodziły w symbiozę z „żywąa” tkanką aktorów można wymienić m. in: szafę maszynę pogrzebowa, wózek na śmieci, maszynę aneantyzacyjna, ławki z Umartej klasy, pokój z Wielopola, Wielopola ${ }^{35}$.

T. Kantor nieustannie próbował dociec tajemnicy zależności między przedmiotem biednym i tkanką ludzkiego ciała. Był czujnym obserwatorem. Podczas swoich europejskich wojaży przyglądał się kloszardom - postaciom, które cenił za, jak to sam określił, „niezależną ludzką filozofię ${ }^{\prime \prime 36}$. W tekście zatytułowanym Coś zapisał: „Spotkałem kloszarda, który wedle zasady swego klanu omnia mea mecum porto - był monstrualnym, obładowanym wielbłądem, miał na sobie wiele płaszczy, derek, płacht, kapeluszy, masę toreb różnego rodzaju, większych, mniejszych, wypchanych, wiszących na sznurkach, paskach. Szyja owinięta licznymi szalami. Wszystko to czarne, wyświecone i wytłuszczone. (...) Odizolowany potwornie grubą warstwą od zewnętrznego świata, skonsolidowany od wewnątrz, stanowiłjednolitą całość' ${ }^{\prime \prime 7}$. Z pewnością inspirowały go podobne indywidua, może nieco podejrzane, zazwyczaj traktowane przez społeczeństwo marginalnie. Zdawał sobie sprawę z ważności l'esprit takiej postaci. Dzięki ewolucji modelu i koncepcji „ludzi wędrowców” powstawały kolejne charaktery, obrazy i happeningi (Ambalaże ludzkie, Wędrowcy i ich bagaże, Trupa wędrowna, Idea Sztuki jako podróży). W 1964 r. T. Kantor napisał Manifest ambalaży, z kolei kilka lat później Emballage humain: „A m b a l a ż z żywym, ludzkim "wnętrzem«. Aktu zapakowywania dokonuję kilkakrotnie. (...) Jest to już czysty r y t u a ł, pozbawiony kompletnie symbolizowania, czysty, o s t e $n$ t a c y jn y akt. W roku 1965 w happeningu Cricotage w Warszawie. 1966 w happeningu Linia podziału w Krakowie. 1967 w happeningu Le grand Emballage w Bazylei. 1968 w filmie Kantor ist da w Norymberdze" ${ }^{\prime \prime 38}$.

Słowo ambalaż (od francuskiego emballer) oznacza czynność opakowywania osób, przedmiotów i dzieł sztuki. Nazwa została utworzona przez T. Kantora na wzór słowa kolaż (collage), określającego postawę artystyczną awangardy lat dwudziestych i trzydziestych. Swego czasu T. Kantor zajmował się również owymi kolażami. Wprowadzał do obrazu "gotową" realność surowa, która intrygowała swoim własnym „życiem”, historia, strukturą. Przytwierdzanie przedmiotów do obrazu okazało się jednak niewystarczające. T. Kantor potrzebował, jak sam to określił, rytuału opakowywania, aby przedmiot „biedny" włączyć w sferę sztuki. Proces wydobywania przedmiotów „najniższej rangi” z rejonów pogardy i śmieszności stanowił dla niego „akt czystej poezji” ${ }^{\prime \prime 3}$. Ambalaż - czynność i proceder zarazem - realizował ludzką potrzebę ochrony, izolowania, zbierania i przechowywania. Dzięki tej metodzie twórczej udało się T. Kantorowi połączyć malarstwo, rzeźbę oraz działanie sceniczne, happening, a nawet rytuał. Istota ludzka stała się cząstką elementarna, bazą dla „zrośniętych” przedmiotowych warstw ${ }^{40}$.

T. Kantor traktował materię jako pramatkę formy. Przy okazji rozważań dotyczących iluzji fabularnej i literackiej zapisał: „Tekst (dramat), jego tok niczym niepowstrzymany prowadzi nieuchronnie do tworzenia się, narastania, nawarstwiania iluzji. Iluzji fabularnej i literackiej. Instynktownie odczuwam konieczność nieustannego rozpuszczania owej rozrastającej się i pasożytującej iluzji, aby nie stracić kontaktu z dnem, którym ona płynie, z elementarna, pre-tekstową rzeczywistością teatralna, autonomiczna, "pre-egzystencją « sceniczna, ową »Ur-Materie« sceny" ${ }^{\prime \prime 1}$. Co prawda zdarza się, że artystyczne refleksje i postulaty T. Kantora brzmią nieco enigmatycznie, ale raczej trudno nie dostrzec, że opisana przez artystę pre-egzystencja sceniczna jest kolejnym wariantem rozumienia materii, która tym razem, w konfrontacji z tekstem, jawi się właśnie jako pre-tekstowa rzeczywistość i co może się wydać frapujące, $w$ takim rozumieniu materia przestaje być wyłącznie intrygującym konceptem, a nabiera cech źródłowego chaosu - boskiej gliny.

Zajmując się statusem materii w twórczości autora Umartej klasy, nie sposób nie wspomnieć o pokrewieństwie wyobraźni twórczej T. Kantora i jego ważnego antenata - B. Schulza. W Sklepach Cynamonowych na temat materii wypowiada się ojciec Jakub. Schulzowski system metafizyczny został zawarty w opowiadaniach, będących cyklem nauk/ „wykładów” Jakuba z udziałem Adeli, Poldy, Pauliny oraz milczącego Józefa. Zdaniem ojca Jakuba: „Materia jest najbierniejszą i najbezbronniejszą istotą w kosmosie. Każdy może ją ugniatać, formować, każdemu jest posłuszna. Wszystkie

35 Tamże, s. 398-406.

36 T. Kantor, Pisma, T. I, dz. cyt., s. 328.

37 Tamże, s. 297.

38 Tamże, s. 317

39 Tamże, s. 306.

40 Zob. T. Kantor, Rezerwat ludzki, [w:] Tenże, Pisma, T. II, dz. cyt., s. 326-328. Tekst T. Kantora napisany do katalogu wystawy pod tym samym tytułem z 1974 r. w krakowskiej Galerii Desa.

41 T. Kantor, Pisma, T. I, dz. cyt., s. 391. 
organizacje materii są nietrwałe i luźne, łatwe do uwstecznienia i rozwiązania"42. Wypowiedź Jakuba nabiera również cech manifestu. W słowach ojca pobrzmiewa ton proklamacji demiurgii wtórej, heretyckiej, kacerskiej: „,hcemy stworzyć po raz wtóry człowieka, na obraz i podobieństwo manekina" ${ }^{\prime \prime 3}$. W rezultacie dochodzi do uwznioślenia, apologii tandety, która ujawnia zarazem „pałubiastość” (chropowatość) materii: „Nie ma materii martwej- nauczał [Jakub - przyp. autorki] - martwota jest jedynie pozorem, za którym ukrywają się nieznane formy życia. Skala tych form jest nieskończona, a odcienie i niuanse niewyczerpane. (...) Po prostu porywa nas, zachwyca taniość, lichota, tandetność materiału. (...) Czy przeczuwacie ból, cierpienie głuche, niewyzwolone, zakute w materię cierpienie tej pałuby, która nie wie, czemu nią jest, czemu musi trwać w tej gwałtem narzuconej formie, będącej parodią? (...) Nadajecie jakiejś głowie z kłaków i płótna wyraz gniewu i pozostawiacie ją z tym gniewem, z tą konwulsją, z tym napięciem raz na zawsze, zamkniętą ze ślepą złościa, dla której nie ma odpływu" ${ }^{\prime \prime 4}$.

Materia, jej wariantywność, metamorficznośći amalgamatyczność mają kluczowe znaczenie szczególnie dla wszelkiego rodzaju peryferii, które w konfrontacji z rozpraszającym się, rozrastającym niczym kłącze centrum stanowią niezwykle "gęsty" i ważki problem w twórczości B. Schulza ${ }^{45}$. Warto wspomnieć w tym miejscu o propozycji interpretacyjnej Adama Lipszyca, który badając ślady tradycji judaistycznej m.in. w prozie poetyckiej B. Schulza, wskazał na pewien - istotny w kontekście poszukiwań T. Kantora - trop żydowskich motywów w dziele autora Sklepótw cynamonowych, mianowicie - judaizm tandety ${ }^{46}$. W opowiadaniach B. Schulza wytrawny czytelnik zwróci uwagę na co najmniej dwa, ściśle ze sobą związane, motywy kabalistycznej proweniencji: primo - Księga, secundo - sztuczny człowiek. Fraza „księga blasku” z Wiosny B. Schulza jest reminiscencją najważniejszego kabalistycznego dzieła Zohar, natomiast termin "golem" pojawia się w Traktacie o manekinach. Jak podkreśla A. Lipszyc, „, Tora, w najwyższym, mistycznym sensie, była dla kabalistów tożsama z Bogiem, studiowanie Księgi było więc równoznaczne z dążeniem do zdobycia najwyższej gnozy. Tę najwyższą postać księgi utożsamiano czasem $\mathrm{z}$ »alef« pierwszą literą hebrajskiego alfabetu, symbolizującą również jedność Boga. Ta sama litera była też jednak kluczowym elementem formuły ożywiającej golema, sztucznego człowieka, na którego czole należało wypisać słowo »emet«, czyli prawda (pieczęć Boga), rozpoczynające się właśnie od tej litery. Zmazanie jej zmieniało ową formułę w słowo "met«, czyli martwy, i uśmiercało golema. Ożywienie sztucznego człowieka było więc manifestacją mocy Boga i jego stwórczej mowy, a zarazem oznaczało dotknięcie najwyższej prawdy, być może więc także - wejście w kompetencje Stwórcy. Na tym głębszym poziomie interpretacyjne poszukiwanie prawdy w Księdze i dążenie do ożywienia golema mogą być postrzegane jako przedsięwzięcia równoznaczne"47.

Zdaniem A. Lipszyca, w takim rozumieniu pisarstwo B. Schulza byłoby współczesną wersją kabały. Co więcej, taka interpretacja wskazywałaby na to, że pojmował on swoją twórczość literacką analogicznie do dążeń kabalistów, „u których granica między odkrywaniem a tworzeniem także pozostawała przecież zatarta"48. Zatem pisanie byłoby rozumiane zarówno jako poszukiwanie prawdy (w Księdze), jak stwarzanie („,praca nad stworzeniem sztucznego człowieka" ${ }^{\prime 49}$ ). Co w takim razie z fascynacją tandeta, o której można mówić w kontekście Księgi (jałowe brednie, pustosłowie, slogany reklamowe) oraz motywu "golemicznego" (pałuby, manekiny, motywy krawieckie w Traktacie o manekinach)? A. Lipszycowi udaje się udowodnić, że właśnie dopiero owa tandeta jest rewelatorską eksplikacją mesjańskich nadziei. Jeśli za jeden z kluczowych punktów w teologii judaistycznej zostanie uznana separacja między światem a Bogiem, może okazać się, że sztuczność, deformacja, tandeta, niepełność, „skrawkowość" i „strzępowatośćc nie utrudniaja, a wręcz przeciwnie pozwalają dostrzec „żydowski” potencjał tej prozy: „moc kontrmityczna, transcendującą - a więc prawdziwie mesjańską - wyobraźnia poetycka okupić musi przejściem na stronę tego, co nie-żywe i sztuczne-tego, co w zderzeniu z immanentnym życiem jawi się jako nieskończenie słabe" ${ }^{\prime \prime 50}$.

Ten kabalistyczny wątek interpretacji B. Schulza wydaje się inspirujący - również w tym znaczeniu, że pewna specyficzna atmosfera „żydowskości” nie była obca T. Kantorowi, który wychował się na pograniczu - w miasteczku, w którym

\footnotetext{
42 B. Schulz, Traktat o manekinach albo wtóra Ksiega Rodzaju, [w:] Tenże, Opowiadania. Wybór esejów i listów, Wrocław 1989, s. 33

43 Tamże, s. 36.

44 Tamże, s. 33-38.

45 Zob. S. Rosiek, Materia, [w:] W. Bolecki, J. Jarzebski, S. Rosiek (red.), Stownik Schulzowski, Gdańsk 2003; W. P. Szymański, Wyznawca Absolutu i Materii - Bruno Schulz, [w:] B. Faron (red.), Prozaicy dwudziestolecia międzywojennego. Sylwetki, Warszawa 1972; S. Chwin, Bruno Schulz-Golem, Demiurg i Materia, [w:] Tenże, Romantyczna przestrzeń wyobraźni, Bydgoszcz 1989.

46 A. Lipszyc, Rewizja procesu Józefiny K. i inne lektury od zera, Warszawa 2011, s. 77.

47 Tamże, s. 78

48 Tamże

49 Tamże

50 Tamże, s. 79
} 
żyli obok siebie Polacy, Ukraińcy i Żydzii ${ }^{51}$. Zarówno motyw Księgi, jak i kreacyjny gest powoływania do życia golema czy manekina, kukły są obecne w twórczości T. Kantora, który niejednokrotnie podkreślał, że kultura żydowska ma kolosalne znaczenie dla kultury polskiej ${ }^{52}$. W jego partyturach pobrzmiewają echa żydowskich kołysanek, pojawiają się chasydzi, którzy dźwigają „Deskę Ostatniego Ratunku” ${ }^{33}$, a cheder jest kluczowym miejscem pamięci Umarłej klasy. Poza tym kacerska demiurgia była bliska T. Kantorowi i jego próbie powołania postaci tak osobliwej, jak kukła, lalka, sobowtór i manekin, których zalążkowa forma w początkowej działalności artystycznej T. Kantora, z czasem ewoluowała do niezbywalnej, jednej z dominujących figur Teatru Śmierci.

Wspomniałam już, że T. Kantor jest ojcem obszernej galerii kuriozalnych postaci. Jest zarazem autorem wielu manekinów, które odegrały niebagatelną rolę w jego twórczości. Zasadnicza różnica między bio-obiektem a manekinem polega na relacji wewnątrz materii, sposobie jej ukształtowania, konstrukcji. Manekin stanowi symulakrum człowieka w odróżnieniu od bio-obiektu, którego uprzywilejowaną częścią składowa, mimo symbiotycznego związku, pozostaje obiekt/ przedmiot. Manekin stał się kolejną postacia, która po Ambalażach ludzkich i Wiecznym weędrowcu w sposób naturalny została włączona do galerii kantorowskich charakterów. W manifeście Teatru Śmierci54 z 1975 r. T. Kantor uzasadnił potrzebę wprowadzenia manekina jako autonomicznej, niezależnej postaci - niczym Gepetto ponownie sięgnął po materię, po czym ukształtowałją na obraz i podobieństwo Schulzowskiego projektu. Manekiny i kukły stały się sygnałem alternatywnej, równoległej rzeczywistości. Ten plastyczny twór T. Kantor rozumiał jako model dla żywego aktora:

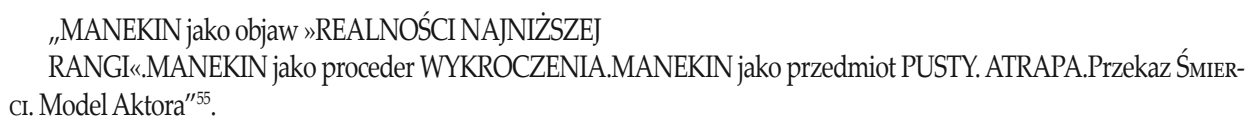

Obcość ewokuje strach i grozę. W manifeście Teatru Śmierci T. Kantor powołał się na swoich poprzedników - Heinricha von Kleista, Ernsta Theodora Amadeusa Hoffmanna i Edgara Allana Poe, których twórczość oraz pisma krytyczne nawiązywały do figury lalki, marionetki bądź kukły ${ }^{56}$.W manifeście T. Kantor dał obszerny wykład na temat rodowodu manekina w literaturze i kulturze. Odrodzenie tego typu postaci - sztucznych kreacji człowieka w XX w. koresponduje z romantyczną antropologią ${ }^{57}$, złożonością ludzkiej natury i motywem sobowtóra: „Na, wydawałoby się, bezpieczną drogę, którą kroczył człowiek Oświecenia i Racjonalizmu, wychodzą z ciemności nagle i coraz liczniej soBOWTóRY, MANEKINY, AUTOMATY, HOMUNKULUSY. Twory sztucznie stworzone, uragające tworom NATURY, niosące w sobie całe poniżenie, wSZYSTKIE marzenia ludzkie, ŚMIERć, Horror i Grozę. (...) Wszystko to jeszcze w oparach demonizmu, na pograniczu szarlatanerii, nielegalnych praktyk, magii przestępstwa i koszmaru" ${ }^{\prime \prime 58}$. Otóż, właśnie w koncepcjach filozoficzno-artystycznych XIX w. T. Kantor doszukiwał się narodzin wiary w możliwość wypreparowania sztucznego mechanizmu ludzkiego, który dzięki perfekcji wykonania przewyższałby swoimi możliwościami żyjące istoty. Wiek XIX wyprzedził science fiction XX w. Manekiny w twórczości T. Kantora przejęły funkcję dodatkowych organów, pasożytujących na ciele aktorów narośli. W Umarłej klasie pojawia się szereg postaci-kreatur, które na swoich plecach dźwigają kukły (trupki dzieci). Kukły nie były wyłącznie sygnałem śmierci epoki dzieciństwa. Dzięki nim została również zobrazowana niemożność opisania człowieka hic et nunc. Istota ludzka jest w ciaggym procesie narodzin i śmierci. Nie można rozmawiać o niej, nie uwzględniając jej

51 Zob. P. Krakowski, Szkolne lata Tadeusza Kantora, [w:] J. Chrobak, J. Michalik (red.), W Tarnowie i Krakowie. Szkolne lata Tadeusza Kantora 19241939 wraz z uzupetnieniami do roku 1944, Kraków 2009.

52 W Krakowie w Galerii-Pracowni T. Kantora przy ul. Siennej 7/5, w ramach projektu Kto inspiruje? Tadeusz Kantor!, do 31 V 2014 r. można odwiedzać wystawę o nieco „szkolnym” tytule Motywy żydowskie w twórczości Tadeusza Kantora.

53 Genealogia tego przedmiotu biednego jest obszerna - w skrócie rzecz ujmując, Deską Ostatniego Ratunku okazują się praca pamięci i wspomnienie - jako dwie instancje konstytuujące tożsamość. Zob. M. Porębski, Deska T. Kantor. Świadectwa, rozmowy, komentarze, Warszawa 1997. Co roku 8 grudnia, w rocznicę śmierci T. Kantora, odbywa się happening ,ku chwale pamięci” - Wacław i Lesław Janiccy - aktorzy teatru Cricot 2, tym razem w roli Chasydów, pojawiają się przed muzeum T. Kantora przy ul. Kanonicznej i dźwigając na swych barkach surową drewnianą deskę, zastygają w bezruchu. Ruch uliczny zostaje wstrzymany, a wokół żywych rzeźb gromadzą się przechodnie, turyści, wielbiciele sztuki, aby oddać hołd T. Kantorowi i jego twórczości.

$54 \mathrm{~W}$ tym miejscu można wspomnieć o dającym sie dostrzec pokrewieństwie refleksji teoretycznej w przypadku manifestu T. Kantora i Manifestu Cyborga (1985) autorstwa Donny Haraway. Nie można mówić o inspirowaniu się amerykańskiej feministki wcześniejszym tekstem T. Kantora. Są to oczywiście dwa niezależne teksty powstałe na gruncie odmiennych fascynacji i poszukiwań badawczych oraz artystycznych. Warto jednak zasygnalizować pewną wspólną płaszczyznę eksploracji teoretycznych i kulturowych.

55 T. Kantor, Pisma, T. II, dz. cyt., s. 17.

56 Zob. V. Nelson, Sekretne życie lalek, Kraków 2009.

57 Ponowienia motywu manekina są na ogół wyrazem powinowactw z romantyzmem z wyboru bądź polemicznej reinterpretacji.

58 T. Kantor, Pisma, T. II, dz. cyt., s. 14. 
przeszłości, życie „,nie może toczyć się jedynie na wąskim skrawku czasu teraźniejszego!" ${ }^{\prime 59}$.

Postać manekina wniosła nowe treści do twórczości T. Kantora, któremu udało się wydobyć energię atrapy. Potwierdziła się jego teza, że życie można w sztuce wyrazić tylko przez jego brak oraz pustkę. Tajemnica atrapy polegała na tym, że nie dość, że i ona posiadała swoją „przedmiotową” świadomość, to może dzięki temu, że spełniła już swoje „życie”, była obdarzona pewnego rodzaju świadomością wyższą. Przedmiot zyskał nagłą przewagę dzięki temu, że przepłynął przez niego „groźny przekaz Śmierci i Nicości”"60 zarazem. Materia, tandeta i atrapa implikują treści egzystencjalne, wytrącając człowieka z pewności o jego niezachwianej pozycji w świecie (rodzaj dyskomfortu). W konfrontacji z metamorficznościa, „grymasem” materii, tandeta, które wydają się wieść zupełnie niezależny „żywot”, człowiekowi może okazać się niezbędna rewizja statusu residuum w otaczającej go rzeczywistości. Pewna specyficzna obcość groteskowych figur, surowych przedmiotów sprzęgniętych z postaciami T. Kantora ewokuje nie tylko strach i grozę, ale inspiruje refleksje związane z „"zyytelnością" świata, w którym przyszło żyć człowiekowi. I może właśnie na tym polega moc tandety, która, jak starałam się wykazać, wodzi na pokuszenie.

\section{Bibliografia}

[1] Bakke M., Bio-transfiguracje. Sztuka i estetyka posthumanizmu, Poznań 2010.

[2] Bakke M., Ciato otwarte. Filozoficzne reinterpretacie kulturowyych wizij cielesności, Poznań 2000.

[3] Bakke M., Nieantropocentryczna tożsamość, [w:] A. Gwóźdź, A. Ćwikiel (red.), Medialciało/pamię́. O wspótczesnych tożsamościach kulturoowych Warszawa 2006.

[4] Bakke M., Posthumanizm: człowiek w świecie większym niż ludzki, [w:] J. Sokolski (red.), Człowiek wobec natury - humanizm wobec nauk przyrodniczych, Warszawa 2010.

[5] Borowski W., Tadeusz Kantor, Warszawa 1982.

[6] Chwin S., Bruno Schulz - Golem, Demiurg i Materia, [w:] Chwin S., Romantyczna przestrzeń wuyobraźni, Bydgoszcz 1989.

[7] Domańska E., Ku historii nieantropocentrycznej, [w:] Domańska E., Historie niekonwencjonalne. Refleksja o przeszłości w nowej humanistyce, Poznań 2006.

[8] Fazan K., Gry z komizmem w Teatrze Śmierci, [w:] Fazan K., Projekty intymnego teatru śmierci. Wyspiański - Leśmian - Kantor, Kraków 2009.

[9] Kantor T., Pisma, Metamorfozy. Teksty o latach 1934-1974, T. I, Wrocław-Kraków 2005

[10] Kantor T., Pisma, Teatr Śmieci - teksty z lat 1975-1984, T. II, Wrocław-Kraków 2004.

[11] Kantor T., Pisma, Dalej już nic... Teksty z lat 1985-1990, T. III, Wrocław-Kraków 2005.

[12] Krakowski P., Szkolne lata Tadeusza Kantora, [w:] J. Chrobak, J. Michalik (red.), W Tarnowie i Krakowie. Szkolne lata Tadeusza Kantora 1924-1939 wraz z uzupetnieniami do roku 1944, Kraków 2009.

[13] Królica A., Groteskowe ciata. Kantor i wspótczesna choreografia, „Performer” 2011, nr 2.

[14] Krzysztofek K., Człowiek posthumanistyczny?, „Kultura Współczesna” 1999, nr 1 (19).

[15] Latour, Splatajac na nowo to, co społeczne. Wprowadzenie do teorii aktora-sieci, Kraków 2010

[16] Lipszyc A., Rewizja procesu Józefiny K. i inne lektury od zera, Warszawa 2011.

[17] Nelson V., Sekretne życie lalek, Kraków 2009.

[18] Pleśniarowicz K., Teatr Smierci Tadeusza Kantora, Chotomów 1990.

[19] Porębski M., Deska T. Kantor. Świadectwa, rozmowy, komentarze, Warszawa 1997.

[20] Rosiek S., Materia, [w:] W. Bolecki, J. Jarzębski, S. Rosiek (red.), Stownik Schulzowski, Gdańsk 2003.

[21] Skrzypczak M., Perwersja rekwizytu? Figura uczłowieczona i figura człowieka w twórczości Tadeusza Kantora, [w:] J. Niedbała, J. PodwysockaModrzejewska, B. Prokopczyk, J. Rozwandowicz (red.), Tekst-Tworzywo - Twórca, Łódź 2011.

[22] Stangret L., Umarła klasa, [w:] Wełmiński A., Trumpf, trumpf...: lalki, manekiny i przedmioty ze spektaklu „Umarła klasa” Tadeusza Kantora, Warszawa 2005 .

[23] Schulz B., Traktat o manekinach albo wtóra Księga Rodzaju, [w:] Schulz B., Opowiadania. Wybór esejów i listów, Wrocław 1989.

[24] Szymański W.P., Wyznawwa Absolutu i Materii-Bruno Schulz, [w:] B. Faron(red.), Prozaicy dwudziestolecia międzywojennego. Sylwetki, Warszawa 1972.

\section{Netografia}

[25] Domańska E., Humanistyka nie-antropocentryczna a studia nad rzeczami, http://www.staff.amu.edu.pl/ ewa/Domanska,\%20Humanistyka\%20 nie-antropocentryczna\%20a\%20studia\%20nad\%20rzeczami.pdf, 9.12.2013.

[26] Domańska E. „Zwrot performatywuny" we wspótczesnej humanistyce, http://www.staff.amu.edu.pl/ ewa/Domanska,\%20Zwrot\%20performatywny\%20we\%20wspolczesnej\%20humanistyce.pdf, 9.12.2013.

[27] Haraway D., Manifest cyborga, http://magazynsztuki.eu/old/archiwum/post_modern/postmodern_9.htm, 10.12.2013.

\section{Filmografia}

[28] Miklaszewski K. (reż.), tadeuszkantor@europa.pl 2010.

60 Tamże, s. 18. 